\title{
Application of Gordon's Growth Model for the Transport Sector of Lithuania
}

\author{
Arunas Burinskas $^{1}$, Aurelija Burinskiene ${ }^{2}$ \\ ${ }^{1}$ Vilnius University, Universiteto g. 3, LT-01513 Vilnius, Lithuania \\ ${ }^{2}$ Vilnius Gediminas technical university, Saulètekio al. 11, LT-10223 Vilnius, \\ Lithuania \\ Iarunas.burinskas@evaf.vu.lt; ${ }^{2}$ aurelija.burinskiene@vgtu.lt
}

\begin{abstract}
Even the number of studies has already been carried out on the development of transport sector and the equity value of transport companies, they are considered as two separate topics, and nothing similar has been done so far. This paper seeks to combine both and reviews the situation in Lithuanian context. The application of Gordon's growth model is applied for the sector analysis for the first time, especially for the estimation of the equity value of the transport sector. By the end, the connection between trade flows and the development of the transport sector is presented. Based on the results of the analysis, the insights for the transport sector are provided. The development of Lithuania transport sector is also compared with the tendencies on EU-28 level.
\end{abstract}

Keywords: Transport sector, Gordon's growth model, Lithuania case, equity value.

\section{Introduction}

There are some studies that involve Gordon's growth model for company analysis. However, the number of studies is exceptionally low. The purpose of this research is the use of a Gordon's growth model for financial analysis of Lithuania transport sector. This is the first time than authors apply Gordon's growth model for sector analysis. In the research methodology the application of Gordon's growth model for the estimation of equity value of Lithuania transport sector is presented. In the research, the authors suggest extending the application of Gordon's growth model from companies to sector cases. The main finding is the application of Gordon's growth model and the identification during analysis the change of equity value that is linked with the trend of sales of Lithuania transport sector. These results are 
presented under conclusions. Research limitation is time period: the research is delivered for a 2000-2017 timeframe. For the future, the study could review other periods and economic indicators. The authors have incorporated the reinvestment rate. The future studies could incorporate more elements into sector's equity value analysis. For practical implications the presented equity value estimation procedure could be useful for practitioners, which analyze the development of sector and its financial impact. The revision on yearly basis is recommended to identify the trend direction. The research is original. The originality is evident from the application of Gordon's growth model for sector analysis. The study contributes to financial evaluation studies where most of the authors analyze the cases of companies not sectors.

\section{Literature review}

The expansion of the transport sector has a significant impact on the budgets of most territorial public bodies (central state, regions, and municipalities). Besides, in many cases, only a small part of these costs is covered through road taxes. These expenditures of public money are generally justified on the grounds of both welfare efficiency and equity, given the significant social, economic and environmental impact of transport. In terms of efficiency objectives, stakeholders are usually interested in both direct effects (improving the efficiency and quality of the transport sector itself) and external influences such as reducing pollution and congestion. To respond to the trends, authors research many aspects, such as consumption of energy, the reduction of pollution; the life cycle of technology; health connected issues and other elements. There are many authors which delivered research on various topics (Table 1).

Also, authors are developing new solution methodologies applicable for designing green transport (Wanzenböck et al. 2013). Nevertheless, the number of models in green transport is not widely developed, intermodal transportation giving a reduction in greenhouse gas emission or more efficient vehicle routing algorithms are some examples for related research questions. Moreover, there is a strong focus on environmental aspects and efficiency. Further on, higher attention will be given for Lithuania transport sector case.

Lithuania case. In Lithuania, transport sector contributes to 8 percent of GDP and employees 12 thousand employees. This shows important contribution to the economy of Lithuania. Around $83 \%$ of freights is carried by land transport means . So, it shows that the most dominant contribution is created by Lithuania transport companies providing freight delivery services by roads with the average net profitability of 5\% (The Lithuanian Department of Statistics 2019). 
Table 1. Trends in Studies on Transport Sector

\begin{tabular}{|c|c|c|}
\hline $\begin{array}{c}\text { Stage of } \\
\text { Environmental Policy }\end{array}$ & Primary Characteristic(s) & Authors \\
\hline Energy Management & $\begin{array}{c}\text { Sustainability improvement } \\
\text { and control }\end{array}$ & $\begin{array}{l}\text { Abdallah et al. (2013); Hao et al. } \\
\text { (2015); Oberhofer et al. (2014); } \\
\text { Proost et al. (2012); Robinius et } \\
\text { al. (2017); Wang et al. (2007) }\end{array}$ \\
\hline Pollution Prevention & $\begin{array}{c}\text { Improvement of technology } \\
\text { and efficiency }\end{array}$ & $\begin{array}{l}\text { Alaswad et al. (2016); Colvile et } \\
\text { al. (2001); Daraio et al. (2016); } \\
\text { Maibach et al. (2008); } \\
\text { Pongthanaisawan et al. (2013); } \\
\text { Proost et al. (2012); } \\
\text { Xu et al. (2016) }\end{array}$ \\
\hline $\begin{array}{c}\text { Life Cycle } \\
\text { Management and } \\
\text { Industrial Ecology }\end{array}$ & $\begin{array}{c}\text { Focus on life cycle } \\
\text { environmental effects of } \\
\text { processes and technologies }\end{array}$ & $\begin{array}{c}\text { Larson (2006); } \\
\text { Liu et al. (2018); } \\
\text { Singh et al. (2015) } \\
\end{array}$ \\
\hline $\begin{array}{l}\text { Corporate social } \\
\text { responsibility }\end{array}$ & Modeling of zero waste & $\begin{array}{c}\text { Garza-Reyes et al. (2016); Nguyen } \\
\text { et al. (2010); Wanzenböck et al. } \\
(2013)\end{array}$ \\
\hline
\end{tabular}

EU roads carry about three quarters of all land freight traffic. The ability to transport goods to markets safely, quickly, and economically is crucial for international trade development. The rapid growth of trade flows between countries and the implementation of best practices mean a relatively rapid growth of the transport sector in Lithuania as well (Figure 1).

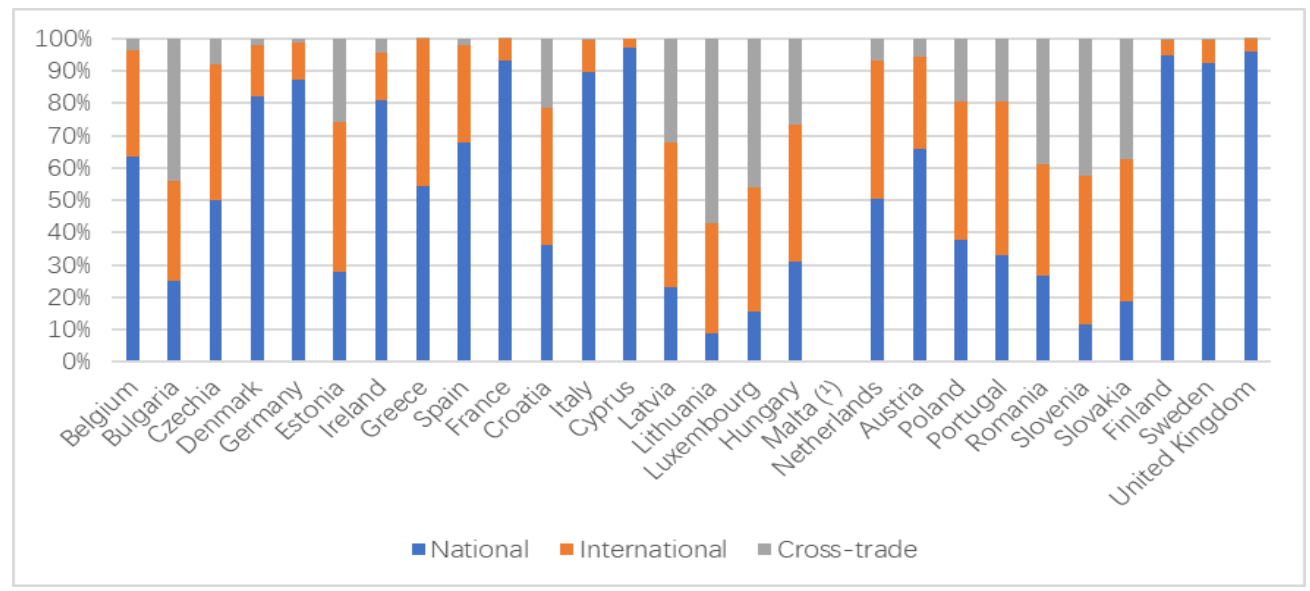

Fig. 1: National and international road transport of goods, 2017 (Eurostat 2019)

In most of EU-countries there is significant growth of national $(3,5 \%)$, 
international $(4,6 \%)$, and cross-trade $(8,5 \%)$ flows. These figures in Lithuania are higher than EU-28 average $(7,2 \%, 16,8 \%$ and $31,1 \%$ respectively) and have a significant impact on the development of the transport sector of the country. Even the transport sector is dependent on the flows of international trade, for further analysis the services provided by land transport are not separated and this data is included in the sector figures together with the data representing other transport services.

\section{Modelling the Transport Sector}

The transport sector could be analyzed on different levels. Under analytical category we have participants, processes, and the level of analysis, which could be linked with function, environment, technology aspects. Such are important categories helping to figure out the equity of sector.

Further on, we must identify the purpose of model. Overall, the transport sector of Lithuania, as the players in EU-28 market is competing with sectors from other countries.

For further analysis, efficiency of sector could be measured, transport prices for services could be compared or the evaluation of financial indicators could be provided.

There are many models which are suitable for modelling various aspects of the transport sector. Some of those models are used for the evaluation, like benchmarking or frontier analysis. Among the evaluation methods is well known for Gordon's growth model.

Table 2. Modelling transport sector

\begin{tabular}{|c|c|c|}
\hline Structural dimension & & Analytical category \\
\hline \multirow{3}{*}{ Transport sector } & Participants & $\begin{array}{l}\text { Carrier, transport service provider, } \\
\text { customers, citizens }\end{array}$ \\
\hline & Level of analysis & $\begin{array}{l}\text { Function, trend, environment, technology } \\
\text { life-cycle, estimation of costs, case study }\end{array}$ \\
\hline & Processes & $\begin{array}{c}\text { Energy consumption, development, R\&D } \\
\text { behaviour }\end{array}$ \\
\hline \multirow{4}{*}{ Modelling } & Purpose of model & $\begin{array}{l}\text { Evaluation through indicators, efficiency } \\
\text { analysis, other economic analysis related to } \\
\text { the efficiency }\end{array}$ \\
\hline & Model type & $\begin{array}{c}\text { Univariate econometric models, } \\
\text { multivariate modelling (cointegration, } \\
\text { causality, etc.) }\end{array}$ \\
\hline & $\begin{array}{l}\text { Econometric } \\
\text { approaches }\end{array}$ & $\begin{array}{l}\text { Parametric versus nonparametric approach, } \\
\text { benchmarking, input-output, costs }\end{array}$ \\
\hline & Solution method & Regression, frontier analysis \\
\hline
\end{tabular}


In accordance with the purpose of the study, we are looking for the equity value of Lithuania transport sector. For such, the authors apply Gordon's growth model. By using this method, we can see the development of sector as well as the operational conditions of transport companies that are evident on the sectoral level.

\section{Data and Methodology}

In this study we, analyze the value dynamics of the Lithuania's transport sector applying a simple valuation model. For this purpose, this study is based on the permanent growth model proposed by Myron J. Gordon where the value of a firm's equity depends on the perpetual growth of the expected next period's dividends (Gordon, 1962):

$$
P_{0}=\frac{D_{0}}{k-g}
$$

where: $P_{0}$ - the current value of firm's equity; $D_{0}$-one-year period dividends that are expected to grow at a constant rate of $\mathrm{g} ; k$ - expected return (stock yield), defined as the discount rate investors use to compute the present value if expected future dividends (the long run expected return of holding stocks).

However, this Gordon's growth model (GGM) was intended for firm's equity valuation only. Therefore, employing it for the appraising the intrinsic value of equity of the whole transport sector, we make some amendments. Firstly, we assume that $k=R O I$, where ROI is estimated as a simple average over the sample period. Secondly, having no data on dividends, we estimate them following the procedure displayed in Figure 2.

To estimate current equity value $\left(P_{t}\right)$, we make some more presumptions. We assume that the sole increase in total equity $\left(E q_{t}-E q_{t-1}\right)$ is due to gained earnings $\left(E_{t}\right)$; and their rate reveals what part of earnings is being reinvested, i.e. retention ratio $\left(b_{t}\right)$.

$$
b_{t}=\left(\frac{E q_{t}-E q_{t-1}}{E_{t}}\right)
$$

Having estimated the reinvestment rate, we proceed with an approximation of dividends, returns on investments $\left(R O I_{t}\right)$, and growth rate $\left(g_{t}\right)$.

$$
\begin{aligned}
D_{t} & =E_{t} \times\left(1-b_{t}\right) \\
R O I_{t} & =\left(\frac{E_{t}-E_{t-1}}{E_{t} \times\left(b_{t}-1\right)}\right) \\
g_{t} & =R O I_{t} \times b_{t}
\end{aligned}
$$




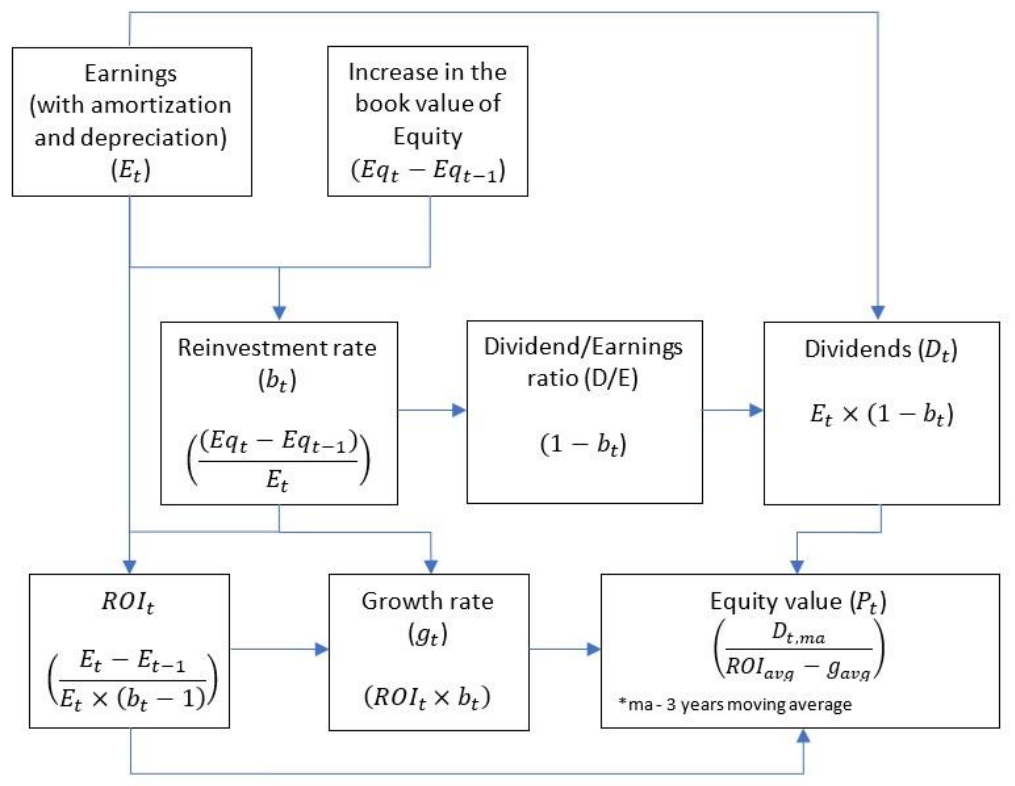

Fig. 2: Equity value estimation procedure

(Constructed by authors)

Taking into consideration that GGM was designed for a long term perspective, we estimate returns on investment $\left(R O I_{a v g}\right)$ and growth rate $\left(g_{\text {avg }}\right)$ as simple averages over the sample period. Also, we assume that being not sensitive for yearly earnings fluctuations, the value investors are consistent in their estimations. Therefore, we estimate dividends as a moving average for the last three years $\left(D_{t, m a}\right)$. Having estimated and inserted all these variables in Equation 1, we obtain the Gordon's growth formula applicable for an industry sector.

$$
P_{t}=\left(\frac{D_{t, m a}}{R O I_{a v g}-g_{\text {avg }}}\right)
$$

In our research, we use data of the Lithuanian Department of Statistics (2019) that offers the balance data for the whole transport sector in the country. The sample period is from 2000 to 2017.

\section{Research Results and Discussion}

Our research has revealed that, in the transport sector of Lithuania, on average growth rate constitutes $11.20 \%$, while ROI - 25.03\%. However, these estimates have not proved to be statistically significant because of high fluctuations, i.e. variation. The standard deviation for average growth rate and ROI respectively amounts for $21.02 \%$ and $38.46 \%$ (Figure 3 ). 


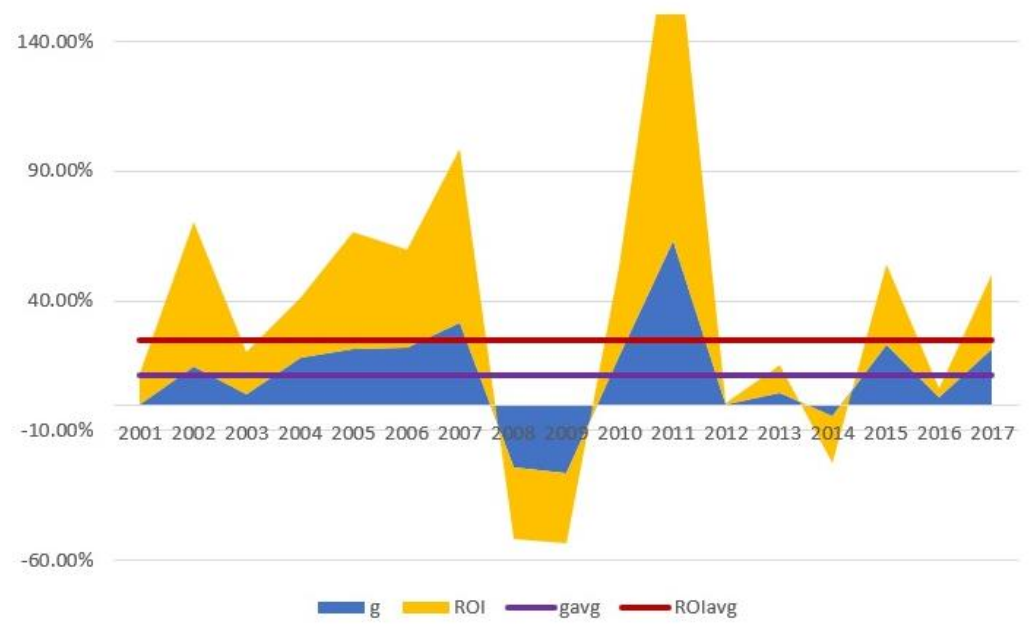

Fig. 3: ROI \& growth rates of the transport sector

Besides, we have found that estimated equity value of the transport sector was like its book value up to 2010 when it started diverging. This divergence continued until very 2016-2017 when increasing D/E ratio together with earlier increased earning realized in higher equity value (Figure 4 and Figure 5).

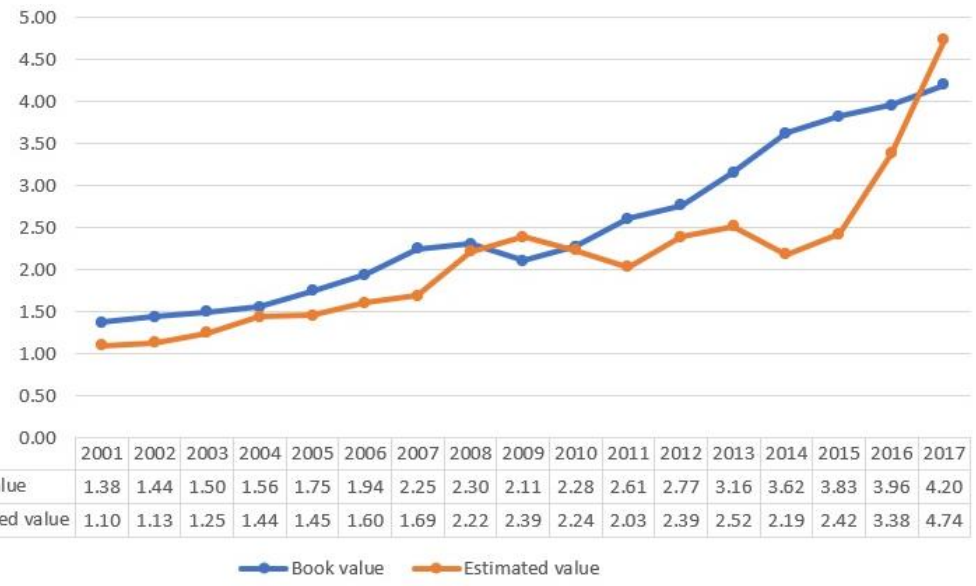

Fig. 4: Estimated \& book equity values of the transport sector, mln Euro

Our findings have revealed that the equity value in the sector quadrupled over the sample period, while, in its last two years (from 2016 to 2018), it almost doubled. 


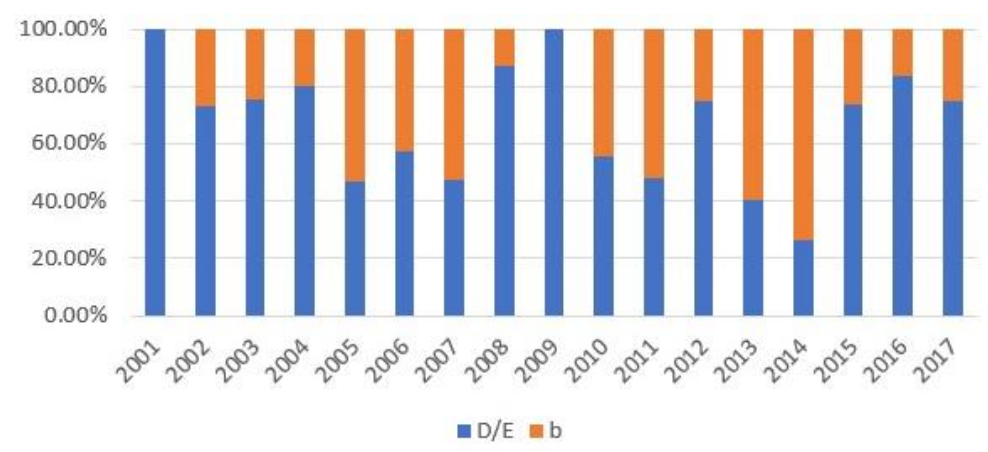

Fig. 5: D/E and retention (b) ratios

The absolute growth of sales has 5 times increase in the period of 2001-2017 (Figure 6). However, during this period, the growth was not stable all over and represented the impact of the crisis. According to the table under Figure 4, the estimated value of the sector was slightly higher than the book value in 2009 and much lower in 2014.

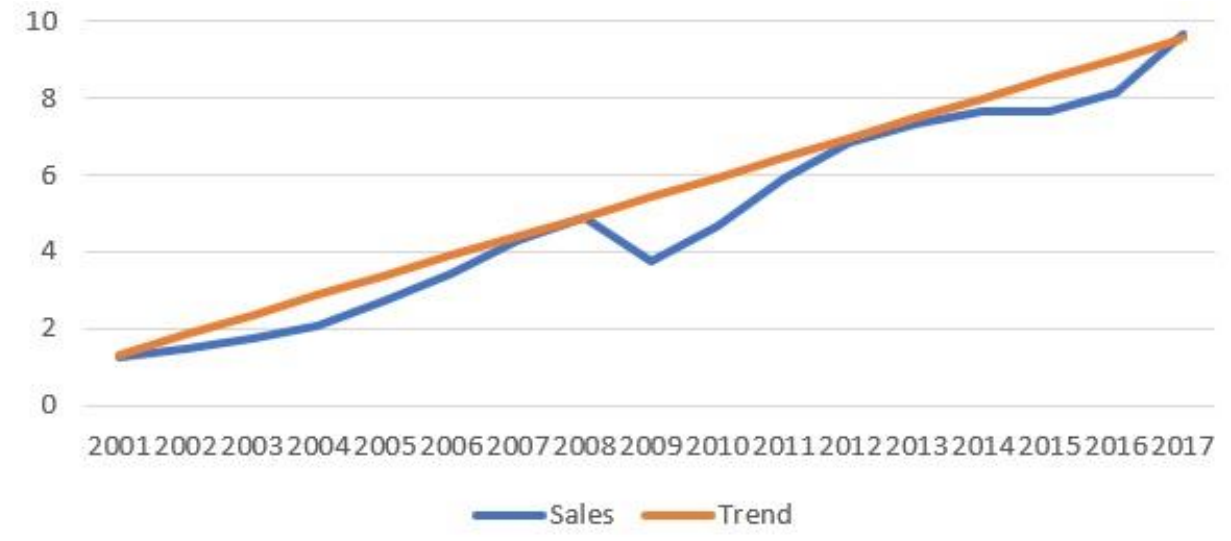

Fig. 6: Sales and its trend in the transport sector, mln Eur

The sector has two down times in 2008-2009 and 2014-2015. The chart 6 matches the growth rates reported in Figure 3 and represntes statistical fluctuations as reported before.

\section{Conclusion}

The research on transport sector has many directions. Although, the most significant attention is given to energy and pollution questions. From 2001 to 2017, the absolute growth of sales was five times. Moreover, on the Lithuania level, the increase in flows was higher than the EU-28 average. The Gordon's growth model belongs to the category of evaluations methods and follows the equity value 
estimation procedure. The application of Gordon's growth model has practical results for companies and sector analysis. It suits for the estimation of the equity value of the transport sector in Lithuania and benchmarking purposes. The research results show that for the transport sector of Lithuania, on the average growth of earnings per year constitutes $11.20 \%$, while ROI is $25.03 \%$. Our findings show that the equity value in the sector quadrupled over the sample period, while, in the period 2016-2018 was almost doubled.

The research could be expanded to other directions, like the application of Gordon's growth model for other time periods or the financial estimation of transport sectors in other countries; revision of various macroeconomic indicators which influence the development of sector and its results; also benchmarking with the growth of service sectors on national and international level.

\section{References}

Abdallah, K. B., Belloumi, M., and De Wolf, D. (2013). Indicators for sustainable energy development: A multivariate cointegration and causality analysis from Tunisian road transport sector. Renewable and Sustainable Energy Reviews, 25, 3443.

Alaswad, A., Baroutaji, A., Achour, H., Carton, J., Al Makky, A., and Olabi, A. G. (2016). Developments in fuel cell technologies in the transport sector. International Journal of Hydrogen Energy, 41(37), 16499-16508.

Colvile, R. N., Hutchinson, E. J., Mindell, J. S., and Warren, R. F. (2001). The transport sector as a source of air pollution. Atmospheric environment, 35(9), 15371565.

Daraio, C., Diana, M., Di Costa, F., Leporelli, C., Matteucci, G., and Nastasi, A. (2016). Efficiency and effectiveness in the urban public transport sector: A critical review with directions for future research. European Journal of Operational Research, 248(1), 1-20.

Eurostat (2019). Database, https://ec.europa.eu/eurostat/data/database. Retrieved on July 10, 2019.

Garza-Reyes, J. A., Villarreal, B., Kumar, V., and Molina Ruiz, P. (2016). Lean and green in the transport and logistics sector-a case study of simultaneous deployment. Production Planning \& Control, 27(15), 1221-1232. 
Gordon, M. J. (1962). The investment, financing, and valuation of the corporation. Homewood, IL: RD Irwin.

Hao, H., Geng, Y., Li, W., and Guo, B. (2015). Energy consumption and GHG emissions from China's freight transport sector: scenarios through 2050. Energy Policy, 85, 94-101.

Larson, E. D. (2006). A review of life-cycle analysis studies on liquid biofuel systems for the transport sector. Energy for sustainable development, 10(2), 109126.

Liu, L., Wang, K., Wang, S., Zhang, R., and Tang, X. (2018). Assessing energy consumption, $\mathrm{CO} 2$ and pollutant emissions and health benefits from China's transport sector through 2050. Energy Policy, 116, 382-396.

Maibach, M., Schreyer, C., Sutter, D., Van Essen, H. P., Boon, B. H., Smokers, R. and Bak, M. (2008). Handbook on estimation of external costs in the transport sector. Ce Delft, 336.

Nguyen, H. O., and Tongzon, J. (2010). Causal nexus between the transport and logistics sector and trade: The case of Australia. Transport policy, 17(3), 135-146.

Oberhofer, P., and Dieplinger, M. (2014). Sustainability in the transport and logistics sector: Lacking environmental measures. Business Strategy and the Environment, 23(4), 236-253.

Pongthanaisawan, J., and Sorapipatana, C. (2013). Greenhouse gas emissions from Thailand's transport sector: Trends and mitigation options. Applied Energy, 101, 288-298.

Proost, S., and Van Dender, K. (2012). Energy and environment challenges in the transport sector. Economics of Transportation, 1(1-2), 77-87.

Robinius, M., Otto, A., Heuser, P., Welder, L., Syranidis, K., Ryberg, D. S. and Stolten, D. (2017). Linking the power and transport sectors-Part 1: The principle of sector coupling. Energies, 10(7), 956-968.

Robinius, M., Otto, A., Syranidis, K., Ryberg, D. S., Heuser, P., Welder, L. and Stolten, D. (2017). Linking the power and transport sectors-Part 2: Modelling a sector coupling scenario for Germany. Energies, 10(7), 957-969. 
Singh, S., Jain, S., Venkateswaran, P. S., Tiwari, A. K., Nouni, M. R., Pandey, J. K., and Goel, S. (2015). Hydrogen: A sustainable fuel for future of the transport sector. Renewable and Sustainable Energy Reviews, 51, 623-633.

The Lithuanian Department of Statistics (2019). Database. www.stat.gov.lt. Retrieved on November 10, 2019.

Wang, C., Cai, W., Lu, X., and Chen, J. (2007). CO2 mitigation scenarios in China's road transport sector. Energy Conversion and Management, 48(7), 21102118.

Wanzenböck, I., Scherngell, T., and Fischer, M. M. (2013). How do firm characteristics affect behavioural additionalities of public R\&D subsidies? Evidence for the Austrian transport sector. Technovation, 33(2-3), 66-77.

Xu, B., and Lin, B. (2016). Differences in regional emissions in China's transport sector: determinants and reduction strategies. Energy, 95, 459-470. 